\title{
КОНКУРЕНЦИЈА И КОЕГЗИСТЕНЦИЈА НОРМИ У КЊИЖЕВНОМ ЈЕЗИКУ ХVIII ВЕКА КОД СРБА
}

Сербокроатисти боље од свих осталих слависта познају ситуацију егзистирања покрајинских (дијалекатских) норми у књижевности и књижевној пракси. Њима се пружа могућност да посматрају ту ситуацију и данас. Чак се може рећи да се у садашњим приликама активизирала књижевна и филолошка тежња према народном „ненормираном” језику, према дијалекатском couleur locale. Примера има доста. Сетимо се чакавског и кајкавског феномена, богатих традицијама и локалним варијантама, па чак и најновијих покушаја, као што су приче на буњевачком говору Анте Секулића, поеме Рече ми један чоек Матије Бећковића са изразитим црногорским (ровачким, брђанским) језичким обележјем, и други. Додуше, слободна употреба дијалектизама била је типична за знатни део српских и хрватских писаца XIX и XX в. од Његоша до Андрића и од Мажуранића до Крлеже. Али то је једно посебно питање, које ћемо овог пута оставити по страни. Употреба дијалектизама не крши књижевнојезичку норму, не тежи ка стварању друге, нове норме или према мешавини двеју или више норми, већ се врши у одређеној пропорцији и одређеном односу према јединственој књижевно-језичкој норми, најчешће из стилистичких разлога. У посебним случајевима и у одређеном књижевно-историјском контексту можемо схватити употребу дијалекта у песничким, појединим драмским и другим делима као активно залагање за нове језичко-стилске путеве, границе и домене. У том циљу Рус Хлебников ствара свој „заумни језик”, а Србин Бећковић искоришћује оно што му пружа народна говорна ризница.

Истовремена употреба двеју или више норми (на пример, код Назора или Франичевића) не ствара конкуренцију норми, већ извесну њихову хијерархију. Једна је норма за писца и за све остале поливалентна (проширена на све функције књижевног језика), друга - жанровски знатно ограничена и хијерархијски локализована. Осим хијерархијске 
локализације можемо одредити за другу „паралелну норму” и географску локализацију. ${ }^{1}$

На тај начин у целини се ствара један доста слободан, „отворен”, функционално погодан и стилистички ефективан нормативни систем који је у исто време и факултативан, јер се „паралелна” или споредна, покрајинска, локална норма може уопште негирати. Такве су данашње књижевнојезичке нормативне прилике у Југославији и неким другим европским земљама у Немачкој, Шпанији, Француској, Италији. ${ }^{2}$ Те прилике су карактеристичне за скоро читаво романско подручје и за део германског подручја, док су се код Словена оне више испољиле у оном делу данашње и историјске Славије (општесловенског језичког подручја) који није спадао у грчко-словенски културни ареал (Рах Slavia Orthodoxa), где је био коришћен црквенословенски језик, дакле у apeaлy Slavia Latina, где је у Средњем веку и у касније време функционисао латински као међународни научни и књижевни језик. ${ }^{3}$ Међутим Пољаци, а углавном и Чеси, нису знали за покрајинске, „дијалекатске” књижевне језике. ${ }^{4}$

О узроцима те различите културно-језичке организованости код Словена казаћу неколико речи доцније. За сада бих истакао само да се у погледу егзистирања више норми делом слична, али принципијелно другачија ситуација запажа код Срба у XVIII в. и почетком XIX в.

Према познатој Унбегауновој периодизацији књижевног језика код Срба ${ }^{5}$ предвуковско столеће дели се на три раздобља: прво - од сеобе Србаља 1690. до 1740, друго - од 1740. до 1780. и треће - од 1780. до првог издања Вуковог речника, тј. отприлике до 1818. Сле́дећи ту

1 Ова географска локализација подстиче неке истраживаче на негирање норме у „дијалекатској књижевности”.

2 Средином XX столећа у Италији је забележен знатан продор дијалеката у лепу књижевност (код писаца Пазолинија, Гаде, Мастронардија, Феноља Давија, Кастеланета и др.) који је чак добио назив „дијалекатске експлозије” (esplosiono dialettale).

3 у тај би ареал од Јужних Словена спадали Словенци и Хрвати. Ипак код Хрвата општа културно-лингвистичка ситуација није била једноставна, јер су глагољаши неговали и црквенословенску (глагољашку) културу и језик, и на тај начин спајали два велика словенска културна ареала.

4 Кашупски је према мишљењу низа еминентних пољских и руских научника посебан словенски језик, зато га овде не узимамо у обзир. За чешко подручје можемо навести такозвани љашки покрајински књижевни језик чији је најистакнутији и у неку руку једини представник чувени песник Ондра Лисогорски.

5 B. Unbegaum, Les débuts de la langue littéraire ches les Serbest, Paris, 1935. 
периодизацију долазимо до констатације да у првом раздобљу, па и другом, још нема конкуренције разних норми. До 1740. црквенословенски језик српске редакције и такозвани србуљски тип језика су у пуној употреби, а то значи да се није одустајало од чувања многовековних традиција старе српске књижевности и културе. Ипак и код Рачана, нарочито у Јеротија Рачанина, као и код Гаврила Стефановића Венцловића, налазимо по коју особину рускословенског језика, управо руске редакције истог црквенословенског језика. Понављам - ту нема конкуренције норми, по среди је само незнатна интерференција, спорадична употреба за почетак XVIII века нових форми под још слабим руским утицајем. Што се тиче Венцловићевог народног језика, који је привукао доста велику пажњу истраживача, ${ }^{6}$ морамо признати да му се често одређује знатно већа улога него што је он у ствари имао у своје доба. Жанровски доста изолиране проповеди монаха Гаврила нису у XVIII веку излазиле ван граница једне од најудаљенијих српских парохија у Северној Мађарској, у Ђеру на Дунаву. У том случају не може бити ни говора о норми, јер норма тражи већу проширеност, сталнију употребу - она тежи за свеопштим признањем.

Друго раздобље - четрдесет година, од 1740. до 1780, опет није знало за конкуренцију норми. Конкуренције није било, јер се стара србуљска норма у то време повукла, те је уместо ње дошла нова „рускословенска” норма. Срби нису одбацили традиционални црквенословенски језик, они су само променили његов тип, прихвативши овај руски као модернији и боље изграђен за нове прилике. То је резултат руског утицаја, руских школа код Срба, жеље да се књижевни језик Срба уклопи у међусловенски (за православно словенско подручје) књижевни језик, да се сачува вишевековна традиција припадања јединственом културном и верском грчко-словенском свету (Pax Slavia Orthodoxa). Зна се да је то припадање било и од политичког и националног значаја, јер је штитило од етничке асимилације (германизације, мађаризације), јачало националну свест, културне везе и културни развој. Тај продор је био јачи у некњижевним „жанровима” (приватна и званична преписка, школска и грађанска акта и сл.), а знатно мањи, па понекад и скоро ништаван, у црквеним, историјским, драмским и филолошким делима. Ипак, постајао је известан број текстова у којима је народни језик превладао остале компоненте.

${ }^{6}$ На жалост, до дан данас немамо научног издања уникалних Венцловићевих рукописа - преводних проповеди. Драгоцена за историју српског књижевног језика грађа остаје неприступачна широј научној јавности. 
Не може се прећутати знатна улога Захарија Орфелина у стварању књижевнојезичке ситуације у XVIII в. Орфелинова делатност, која хронолошки већим делом припада другом периоду историје књижевног језика Просвећеног века, била је усмерена на стварање трију доста слободно схваћених норми књижевног језика. Те „норме” су допуштале у ствари употребу трију језика или „стилова” (према руској терминологији оног доба) у књижевности и књижевном стваралаштву истог писца. Орфелинова концепција и пракса створиле су прелазну ситуацију коју је доцније прихватио и Јован Рајић, а која је наговештавала покушаје и струјања трећег периода, тј. краја XVIII в. и почетка XIX в. Настојања 3. Орфелина да се изграде различити типови књижевног језика и да се употреба тих типова стави у везу са жанровима, са жанровским системом књижевности XVIII в., била су у духу традиција старе српске књижевности (и њене језичке структуре) која је у знатној мери ишла истим путем. О зависности језика од литерарног жанра одговарајућег дела старе српске књижевности имао сам прилику да говорим на VIII међународном научном састанку слависта у Вукове дане. ${ }^{7}$

За српски XVIII век, као и за руски, украјински, бугарски и др. може се поред снажних иновација констатовати и континуитет ранијег књижевнојезичког система који није тражио по ли в а лен тн ост (термин А. В. Исаченка) књижевног језика, тј. његову употребу у свим функцијама, већ је одређивао за разне жанрове чак и разне језике, и допуштао за поједине жанрове употребу народног или још неизграђеног („провизорног”) књижевног језика. XIX век је одлучно и бескомпромисно тражио јединствену норму за све жанрове и за све функције књижевног језика без конкуренције и коегзистенције норми.

Орфелин је својим књижевним, историјским, педагошко-приручним и песничким делима испољио тежњу ка жанровској разгранатости српске књижевности. Истовремено је тражио различита језичка средства за различита дела. Битно је сада напоменути један доста рани Орфелинов покушај да се за исти текст искористе две језичке норме, два језичка система. Посреди су две разне језичке и поетске редакције „Плача Сербіи...” 1761. и 1762 (или 1763.):

7 Н. И. Толстој, Однос старог српског книшког језика према старом словенском книжевном језику (у вези са развојем жанрова у српској књижевности), Научни састанак слависта у Вукове дане, Београд, 1980, 8. 
Прва:

По ланить биють

Скрежещутъ зубами,

Власи на мечъ вїютъ,

Топаютъ ногами:

Чада расхищаютъ

Марсу люту даютъ

На жалостъ мнБ горку.

И друга:

Косе мое на Саблю врази мои вїютъ

и ногама тлачуме а по лицу бїиютъ

чада мох прогоне, марсу люту даю

и тимъ Срдцу моему жалости задаю.

„Славено-руски” и, у мањој мери, српски славенизирани, лепо се испољавају у наведеним примерима. То су Орфелинови покушаји. Они, као и доцнији радови истог писца, сведоче да се још не ради о конкуренцији норми. У ствари се предлаже и намеће коегзистенција норми. Али од коегзистенције до конкуренције већ није далеко. Конкуренција настаје у трећем раздобљу које претходи епоси стварања националног књижевног језика.

Непуних четрдесет година, од 1780. до изласка Вуковог Српског рјечника, је време убрзаног књижевног и књижевнојезичког развитка. Нове идеје, нова збивања, нови читаоци и нови писци долазе на књижевно-историјску арену. То су - Доситеј Обрадовић, Јован Рајић, Емануил Јанковић, Јован Мушкатировић, Григорије Трлајић, Лукијан Мушицки, Милован Видаковић, Јоаким Вујић, Гаврило Ковачевић и др. Стварала се нова књижевност која је за разлику од старе, „синтетичке” књижевности добијала ново обележје и нову, „уметничку” суштину, те постаје „уметничка" књижевност. ${ }^{8}$ Систем литерарних жанрова постаје још потпунији, још развијенији него што је био раније. Нови жанрови се стварају током развоја саме српске књижевности и путем превода страних писаца, углавном Француза, Немаца и Руса. Превод са руског је у већини случајева само редакција или прештампавање, јер је руски историјски „слог” XVIII в. примљен код Срба као компонента књижевног језика. Руски језик XVIII века посредује и у случају када се „преводе” дела француских писаца. Све је то врло битно за историју књижевног језика, док

${ }^{8}$ Г. Гачев, От синкретизма к художественности, Вопросы литературы, 1958, No. 4. 
за историчара књижевности може имати споредан значај, особито ако тај историчар проучава развој националне литературе и њене спецификације.

Проблем „својег” и „туђег” историјски се мења и модифицира. Оно што се у XVIII столећу још схватало као „своје”, почетком и средином XIX столећа већ се често тумачило као „туђе”. Осећај припадности ареалу Pax Slavia Orthodoxa слаби и истовремено јача ауторитет и привлачност свог ужег, националног ареала, чије се границе коначно одређују.

Ти су проблеми у ствари нелингвистички. Рекао бих да су они културолошки, историјски и донекле историјско-литерарни. Али их истраживач историје књижевног језика не може мимоићи. Чисто лингвистички се може решавати питање: „Шта се у књижевном језику променило, када и како?”, али питање „Зашто се то променило?” добија одговор само на основу културно-историјских посматрања. Историја књижевног језика је у истој мери културолошка колико и лингвистичка дисциплина.

Зато ћемо продужити наша разматрања књижевно-историјских прилика у трећем раздобљу Просвећеног века. Убрзани литерарни развој на српском тлу, као што је то донекле било и на тлу руском, проузроковао је скоро истовремено, а не постепено настајање неколико литерарних праваца, као што су барок, класицизам, рационализам, сентиментализам и рани романтизам. На другом тлу ови су се правци рађали поступно и сваки нови правац био је у неку руку одбијање претходног. А то је најчешће значило да је сваки поједини писац морао бирати одређени правац и да је за њега истовремена припадност већем броју праваца била немогућа. Осим тога поједини књижевни правци имали су жанрове типичне само за њих, као што је класицизам неговао оду, и сентиментализам елегију. Са жанровима, па чак и са појединим правцима, била су везана конкретна схватања књижевног језика и стила. Књижевни правци су активно конкурисали не само код Срба, већ и у читавој Европи. Конкуренција књижевних праваца налазила се у вези са конкуренцијом жанрова и књижевнојезичких норми па ју је чак и узроковала. Ипак та веза није увек била чврста и апсолутна, јер су постојали други друштвено-историјски, просветни и културни разлози који су стварали ауторитет појединих норми или неповерење према њима. Као што сведочи и сама грађа, тј. текстови XVIII в. и почетка XIX в., било је и доста компромиса, мешавина норми и сл. У ствари ниједна се норма није спроводила доследно. То стање ствари је типично за такозвану „преднационалну” етапу развитка књижевног језика, за доба конкуренције норми. Није све било унапред одређено и условљено - остајало је још доста слободног простора за избор, размишљања и експериментисања. Скренуо 
сам нарочиту пажњу на зависност језика и норме од литерарног жанра одговарајућег дела и литерарног правца коме припада писац дела углавном због тога што сличне опсервације и констатације за српске прилике нису још уобичајене.

Које су норме конкурисале крајем XVIII в. и почетком XIX в., све до изласка Вуковог речника?

a) Архаичка „славеносрпска”, изразито руског типа. Њени су представници били: П. Јулинац, Г. Трлајић, А. Везилић, М. Максимовић, Т. Аврамовић, Г. Хранисављевић, Н. Стаматовић, Н. Авакумовић, Ј. Пејаковић, К. Јосић, Д. Геогријевић, А. Д. Секереш - писци и преводиоци ода, лирских песама, романа.

б) Новаторска „народносрпска” („простое сербское наръчїе”). Њени су представници били: Е. Јанковић, Н. Лазаревић, Ј. Мушкатировић, Ст. Рајић и др. - писци и преводиоци драмских, природописних, историјских и других дела.

в) Црквенословенска руског типа (ретко српског „србуљског” типа). Њени представници су били: Ј. Рајић, К. Живковић и др. - писци и редактори црквено-поучних и хагиографских дела.

Црквенословенски језик у својем чистијем облику, а не као компонента „славеносрпског” или „славеноруског” на српском тлу, крајем XVIII века већ је био врло слаб конкурент другим идиомима, па бисмо га могли чак и не узимати у обзир. Ипак, за језички систем Јована Рајића, писца значајног за XVIII век, он је врло битан и чини основу читаве језичке градације и њених норми. Зато ћемо о Рајићу говорити засебно, као што смо то већ учинили са Орфелином. Александар Белић био је вероватно у праву када је обратио пажњу да Рајићева књижевно-језичка делатност више припада другом раздобљу Унбегаунове периодизације него трећем, и то, разуме се, не хронолошки, већ типолошки. ${ }^{9}$ Рајићева делатност је слична Орфелиновој. Као и Орфелин он ствара књижевно-језички систем од три компоненте - црквенословенски, српски и руски („словеноруски”, тачније - историографски „слог” руског језика XVIII в.). Ниједан од тих језика није био потпуно чист, већ је сваки био прожет елементима одговарајућег другог језичког пара. Као и Орфелин, Рајић предлаже коегзистенцију тих језика уз њихову жанровску дистрибуцију. Рајићев и Орфелинов систем, спроведен у пракси, веома подсећа на Ломоносовљеву теорију „трију стилова” - вишег, средњег и нижег,

9 Види Белићев осврт на поменути Унбегаунов рад „Les débuts...” у Јужнословенском филологу, Б. 1933-1934, књ. ХІІІ, стр. 191-195. 
која је, у ствари, ранијег порекла, али је Ломоносов заслужан за њену популаризацију и ширење код Руса у XVIII веку.

Код Руса, као и код Срба, коегзистенција „трију стилова” (норми) је прешла у борбу тих „стилова” (норми). Као резултат те борбе дошла је победа само једног „стила” (норме, језика). Код Руса је надвладао средњи стил, а код Срба народни („нижи”). Као и код Руса (Карамзин, Пушкин), код Срба је било покушаја да се створи и афирмише средњи „стил”-норма (Видаковић, доцније Његош и др.). Крајем XVIII в. а особито почетком XIX в. свуда се већ мислило на стварање јединствене норме, на прихватање једног језика или једног „стила” (према руском термину XVIII века). Једни су ту норму схватили као средњу према старим трима нормама (језицима, „стиловима”), други као чисто народну, ону, што би се, рачунајући „одозго”, од црквенословенског језика, звала „нижом”. ${ }^{10}$

Кад је код Срба већ у самом почетку XIX в. црквенословенски, на чијој се бази скоро читавог XVIII века, као и раније, градио читав књижевно-језички систем, скоро сасвим повукао из употребе, дошло је до конкуренције „средње” и народне норме и до оштрих окршаја њихових присталица. Победила је, као што је добро познато, народна норма у Вуковом тумачењу. То је створило веома специфичан стилски систем савременог српскохрватског књижевног језика ${ }^{11}$ који отвара врата дијалекатским и локалним струјањима, о чему смо већ говорили у почетку нашег реферата.

Национални књижевни језик је поливалентан. Он тражи изградњу јединствене норме и њену доста строгу и доследну употребу. ${ }^{12}$ Тај услов омогућује егзистирање и локалних, „дијалекатских”, малих књижевних

${ }^{10}$ Код Руса у XVIII в. је познат привремени и неуспели покушај В. К. Тредиаковског да се уведу речи „нижег ранга” („мужицкие, подлые слова”) у тадашњи књижевни језик. Занимљиво је да је Карамзин, као и доцније Вук, предложио паролу „да се пише као што се говори, и да се говори као што се пише”. Само Карамзин се оријентисао према говорном језику московских и петербуршких књижевних и интелектуалних салона, а Вук према језику орача, пастира и гуслара.

${ }^{11}$ Н. И. Толстой, К вопросу о зависимости елементов стиля стандартного литературного языка от характера его „стандартности”. У књизи: Развитие стилистических систем литературных языков СССР, Ашхабад, 1968, стр. $124-134$.

12 Норма појединих фонетских и морфолошких елемената може да има своје варијанте. Те варијанте не крше јединственост норме. Види: К. С. Горбачевич, Изменние норм русского титературного языка, Ленинград, 1971. Исти аутор Вариантность слова и языковая норма, Ленинград, 1978; Л. К. Граудина, Вопросы нормализации русского языка, Грамматика и варианты, Москва, 1980. 
језика. Ти језици су жанровски ограничени и не улазе у систем националног књижевног језика, већ стварају свој аутономни, допунски и непотпун систем, често са врло лабилном „нормом”.

Српски књижевни језик због пређашњег великог и чврстог ауторитета црквенословенског језика није доживео у „преднационалној” етапи своје историје конкуренцију разних локалних (територијалних) типова књижевног језика, конкуренцију локалних провизорних норми или књижевних „преднорми”. Оваква конкуренција је била карактеристична за хрватски (Гај и др.) и особито за словеначки случај. ${ }^{13}$ Али то питање тражи посебно и детаљно разматрање.

Проблем коегзистенције и конкуренције норми код Срба у XVIII веку је тек овлаш скициран у овом реферату. Због тога нисмо могли избећи извесне схематизације и поједине констатације материјалом доста непотврђене. Нешто више чињеница и грађе може се наћи у мом конспективном раду о српском књижевном језику XVIII века. ${ }^{14}$ Питање начина одређивања језичких норми код Срба у XVIII веку је зналачки разраћено у радовима проф. Александра Младеновића. ${ }^{15}$

${ }_{13}$ Н. И. Толстой, О последней питытке применения „Общеславянской азбуки" к словенскому литературному языюку, Проблемы современной филологии, Москва, 1965.

${ }^{14}$ Н. И. Толстой, Литературный язык у сербов в конце XVIII - начале XIX века, Национальное возрождение и формирование славянских литературных языков, Москва, 1978; исти аутор, Литературный язык в XVIII в. (до 1780. г.), Славянское и балканское языкознание, История литературных языков и письменностг, Москва, 1979.

15 А. Младеновић, Типови књижевног језика код Срба у другој половини XVIII u почетком XIX века, Реферати за VII Међународни конгрес слависта у Варшави, Нови Сад, 1973; исти аутор, Однос између домаћих и рускословенских елемената у кюижевном језику код Срба пре юегове Вукове стандардизације, Зборник за филологију и лингвистику (скраћено ЗФЛ) XII, Нови Сад, 1969; исти аутор, O неким рускословенским и српскохрватским језичким особинама у Орфелиновом „Магазину”, ЗФЛ, XIII/I, Нови Сад, 1970; исти аутор, Прилог познавағу односа између српскога и славеносрпскога језика у другој половини XVIII и у првим деценијама XIX века, Научни састанак слависта у Вукове дане, 6, Београд, 1977; исти аутор: О неким питанима и особинама славеносрпског типа књижевног језика, ЗФЛ, XXI/I, Нови Сад, 1978. 